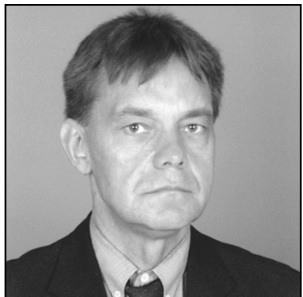

Raul Narits

Professor

of Comparative Jurisprudence

University of Tartu

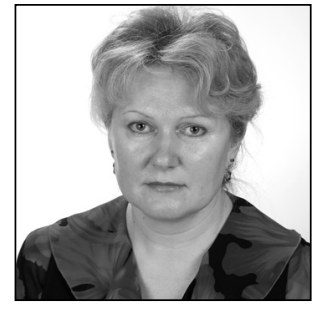

Silvia Kaugia

Dr. iur., Lecturer

of Comparative Jurisprudence University of Tartu

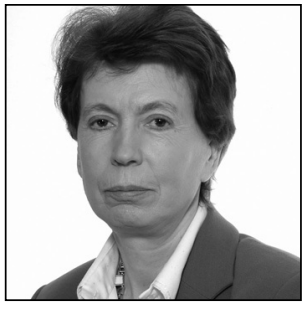

Iris Pettai

PhD, Director

Estonian Institute for

Open Society Research

\title{
Towards a Single Government Approach via Further Consolidation of Law and Order in Estonia, with Domestic Violence as an Example
}

\section{The necessity of including domestic violence in the project for developing better legislative drafting}

The purpose of this article is to advance suitable near-future-oriented solutions for combating and preventing domestic violence (DV) as an acute social problem ${ }^{* 1}$ in Estonia. In the authors' opinion, a suitable approach might consist of an integrated legislative drafting solution in the form of a corresponding legislative act. Accordingly, the article addresses the methodological basis for the consolidation of law and order in presentday Estonia, the local value of sociological empiria, and comparative examination of findings from DV-related surveys carried out by legal practitioners in Estonia. All of these aspects of DV are important for comprehending the activity of consolidation of legal acts that is necessary for Estonia from the standpoint of DV.

One of the most important standards of approach should be found in the Organization for Economic Co-operation and Development (OECD report 'Estonia: Towards a Single Government Approach', which states that Estonia, for reason of its small size, cannot afford fragmentation. Increasing the flexibility of structures, improving communication, overcoming barriers between institutions, and developing supradepartmental strategies must be present on the agenda. ${ }^{{ }^{2}}$

The key to the solution in the rule-of-law context may lie in systematising of the legal norms. ${ }^{*}$ The state can operate only when resting on a sound legal base or a corresponding collection of legal norms, whose

It is important to emphasise from the perspective of legal policy that the President of the Republic of Estonia considered it necessary to emphasise that DV is a highly negative element constituting a social problem in Estonian society in her two latest addresses given on the anniversary of the Republic of Estonia. The text of the speeches is available in English at http:// www.president.ee/en/official-duties/speeches/13091-president-of-the-republic-at-the-estonia-theatre-and-concert-hallon-24-february-2017/index.html and http://www.president.ee/en/official-duties/speeches/14154-the-president-of-therepublic-at-the-estonian-national-museum/index.html (most recently accessed on 6.4.2018).

2 OECD. Estonia: Towards a single government approach. OECD Public Governance Reviews. OECD Publishing 2011. - DOI: https://doi.org/10.1787/9789264104860-en.

3 Fundamental progress can occur only in the form of work de lege ferenda, since the state must possess a legal foundation for every activity. 
interaction in the ideal case should form a single, coherent system. Frequently, formal systematisation is undertaken as an endeavour of arranging the necessary set of basic terms hierarchically, yet it has been correctly pointed out that, while this represents the usual image of systematisation, it is unilateral or even misleading. ${ }^{*} 4$ When regulating some aspect of life via legal norms, one has to differentiate between the legal order and the legal system. Order has always been, as it will remain, a phenomenon of societal use of power. The legislative power approves legal provisions and implements them (in objective law). A system, in contrast, is something much more than the organisation of rule. Since the restoration of Estonia's independence (in 1991), a modern legal order has been developed in most spheres, thanks to organisation of rule. The field of prevention of DV is no exception in this regard. However, with further improvement of the legal order in Estonia it has become evident that the outputs of the efforts toward this organisation of rule require further regulation to give them a more systemic nature. In the case of preventing and combating DV, there is much room for progress in this respect, irrespective of relatively efficient regulative activities in the drafting and implementation of the corresponding legal provisions. What, then, is the problem? When some sphere is regulated by legal provisions, this is done in the ideal case by classifying matters rationally - i.e., by systematising. Figuratively speaking, one can consider matters belonging together on account of their essence to be able to be grouped under the same designations. Hence, attempts can be made to differentiate among them on the basis of obvious features. This process is carried out for every part of life regulated by law, more or less successfully. In consequence, these are drawn together: they are no longer separate elements of organisation of rule but form regulated complexes of legal provisions bound by close internal ties.

This method of systematising the legal order has been used in Estonia for some time already, and important results have been achieved. The Ministry of Justice of the Republic of Estonia is carrying out work of this sort in projects titled 'Revision of Law' and 'Developing Better Lawmaking' in accordance with the Secretary of State's directive 42 of 19 December 2014, on providing support to the implementing institutions' activities for achieving results in relation to Action 12.2, 'Development of Quality of Policy-making', on priority axis no. 12, 'Administrative Capacity'. In general terms, the objective in this connection is rational legislative drafting in those spheres subject to revision, coupled with the development of higher-quality legislative drafting. The main problem faced involves fragmentation into field-specific legal acts and provisions that is wrought through a sector-oriented approach. This restricts comprehending them as a body of law and also obstructs to some degree the realisation of the full potential of the law. Such fragmentation is present in a several spheres, with the set of legal acts and provisions pertaining to DV being no exception. The causes are well-known and characteristic of so-called young legal orders. Among them are the need for rapid reforms, incompatibility between earlier and later acts, differences and even conflicts of interest between departments, and concessions with regard to law's systemic nature that stem from the need to make amendments required by EU law.

To achieve clearer and more systemic legislation, countries belonging to the Continental European law family - including Estonia - have employed codification. The idea of codification is in creating of legal certainty and clarity not merely by streamlining the finding of regulations but also by making use of the full potential of law for organising and protecting. The position of the Ministry of Justice reads: 'Codification also involves the thorough, substantial, and systemic analysis, harmonisation, and updating or revision of already existing codes or laws. ${ }^{*} 5$ The Ministry of Justice is still in the process of updating and regularising the law, continuing efforts that started within the Developing Better Lawmaking ${ }^{*}$ programme and have not yet been completed in all spheres. It should be added that if the field of DV is to be included in the revision process, the already approved specifics for organisation of the codification and revision work, stages of work, and methods for it should be used, just as they have been in the revisions performed for the spheres brought in previously. This framework encompasses various activities characteristic of intelligent lawmaking - simplification, considering of alternatives, analysis of impacts, involvement of stakeholders, etc.

The Developing Better Lawmaking programme has so far extended to the spheres of social law, economic administrative law, environmental law, intellectual property law, and some other fields. The experience

4 A. Aarnio. Õiguse tõlgendamise teooria ['Theory of Interpretation of Law”]. Tallinn: Juura 1996, pp. 224 ff.

5 See the materials on both projects, for revision of lawmaking and the development of better lawmaking, that are available at http://www.just.ee/et/eesmargid-tegevused/oiguspoliitka/oiguse-revisjon (most recently accessed on 6.4.2018) (in Estonian).

6 See http://www.just.ee/et/eesmargid-tegevused/oiguspoliitka/parem-oigusloome (most recently accessed on 6.4.2018) (in Estonian). 
from systematising these spheres should be used as an example in any further systematisation relevant for the sphere of DV. Prerequisite to complete revision (reform and systematising) of the legal acts regulating this field would be an analysis assessing, on the one hand, whether codification for this field is theoretically possible and, on the other, whether it is practically necessary. This entails analysis of the legal acts regulating the field, to enable mapping of the relevant regulations and attempting to find common elements. In turn, for the purpose of ascertaining the practical necessity and performing related analysis, corresponding sociological studies are of inestimable importance. Therefore, this article presents an analysis of surveys carried out among Estonia's legal experts with regard to DV. Furthermore, there can be no doubt of the necessity of applying comparative analysis at the level of the law of the various European Union member countries at least, so as to uncover information about the intent behind corresponding codification, the laws in place, and the extent of the regulation contained in these laws: the information thereby produced can greatly inform our efforts to find the most appropriate solution for Estonia. ${ }^{* 7}$

The section of this article addressing the sociological approach and the analysis provided in the empirically oriented part of the paper should aid in finding answers to various questions related to a possible revision of legal regulations addressing DV. The most important general issue is whether it is necessary in Estonia or even possible to codify the legal acts covering the sphere of DV. However, there is at the same time a set of questions that are easier to answer than this, thanks to empirical studies already carried out ${ }^{*} 8$ : is it possible to draft a general act regulating DV, one that would contain all the general provisions pertaining to the subject; have other countries carried out codification for the sphere of DV, and what has their experience of codification in this arena been (this can afford assessing whether the various aspects of DV being distributed across the domains of separate ministries has resulted in unsystematic regulation of the sphere of DV, examining whether centralising the co-ordination related to DV under one ministry could improve the quality of legal regulation of this subject, and determining the need for compiling a code (a DV act) and the importance of such a code for practice); and how, and to what extent, would the codification (revision) require the amendment of existing acts and the drafting of new regulations?

The Developing Better Lawmaking project achieved its first success in the drafting of the general provisions of the environmental law. This output, among others, shows that seeking systemic solutions should start with an agreement on the essential basic concepts for the relevant sphere. ${ }^{*}{ }^{9}$ Concepts are of decisive importance for any system. It is quite appropriate at this point to recall the teaching of F.C. von Savigny that every concept must have its 'juridical reality' and that only after agreement on the reality is reached i.e., once clarity as to the concepts has been achieved - can legal provisions be arranged into an integrated system. ${ }^{*} 10$ The success in the revision of the environmental law and, for example, the revisiting of penal law came largely as a result of reaching agreement on the set of concepts foundational to the respective sphere.

The more developed a society is and the greater the extent of the institutional underpinnings and mutual co-operation, the more effective that society can be in the prevention of DV and in combating its

For example, the drafting of the preparatory analysis for revising the intellectual property law drew on materials dealing with intellectual property that were published in Estonia and Germany, but alongside these were corresponding legal acts and drafts from Italy, France, Germany, Poland, Portugal, Sweden, and Russia. Reaching the goal for the analysis, especially in respect of assessing interdepartmental co-operation, involved interviews of specialists in intellectual property law and solicitation of their written remarks, with attempts being made to involve a wider circle of individuals, not forgetting individuals whose involvement or views are mainly future-oriented. Officials with the Ministry of Culture, of Economic Affairs and Communications, of Rural Affairs, and of Justice; Patent Office and Competition Authority officials; representatives of the Estonian association of patent attorneys; barristers; and lecturers in jurisprudence at the University of Tartu have contributed to the completion of the analysis. The initial assessments of these respondents were consistently represented in this analysis. The review of other countries' experience is based on international law publications, responses to questionnaires sent to various entities in European Union member countries, and correspondence with responsible officials. The analysis results are available at http://www.just.ee/sites/www.just.ee/files/elfinder/article_files/intellektuaalse_omandi_oiguse_kodifitseerimine._uldosa_voimalikkusest_2011_1.pdf (most recently accessed on 6.4.2018) (in Estonian).

8 Alongside the empirical studies already carried out, there are several further surveys that should be undertaken, since learning the positions of the lawyer community and analysing them cannot provide sufficient grounding for revising the legal order with regard to DV.

9 The Ministry of Justice report whose title translates to 'The First Stage of Codification of the Environmental Law is Complete' points out the following: the part of the law setting forth general provisions regulates for the first time the principles of environment protection at the legislative level and defines the system of concepts of the Estonian environmental code. Report available at http://www.just.ee/et/uudised/keskkonnaoiguse-kodifitseerimise-esimene-etapp-loppenud (most recently accessed on 6.4.2018) (in Estonian).

10 F.C. von Savigny, G. Wesenberg (eds). Juristische Methodenlehre: Nach der Ausarbeitung des Jacob Grimm. Stuttgart: K.F. Koehler 1951, p. 37. 
manifestations. Accordingly, one can conclude with regard to the situation in Estonia that work to develop an integrated juridical solution should exhibit more vigorous strivings to include regulative provisions, in addition to law-enforcement provisions, that would orient the various institutions toward co-operation and co-ordination of mutual activities. ${ }^{* 11}$ Thereby, the requirement of a single, coherent approach to government could be met, in line with the above-mentioned OECD report.

It should be mentioned, however, that not everyone agrees on many aspects of what has already occurred in Estonia and what is currently being done under the Developing Better Lawmaking programme. For example, the Chancellor of Justice has been critical of the developments:

Two lawmaking campaigns, with opposite directions, have been underway in Estonia for years. One of them has the purpose of revising most laws (also known as 'developing better lawmaking', 'codification', etc.), while the purpose of the other is not to make new laws if possible ('less lawmaking'). Keeping this lawmaking machine in operation has taken more than two and a half million euros over the years and will take more money in the coming years - regrettably, often without any useful and necessary results. The so-called revision has been beneficial in some cases (e.g., that of the penal code), but most examples are either contradictory or even negative (e.g., the economic administrative and social codes and the intellectual property and misdemeanour codes). If a law is revised where there is no real necessity, this causes harm. Officials and judges, as well as members of the society concerned with the law, will have to learn the new language and new articles. This means money and expending work hours on training, mistakes, and court debates. ${ }^{*} 12$

While it is difficult to agree with the Chancellor of Justice's view on the necessity of revision since the creation of a systemic structure necessary for legal order is at stake, the 'less lawmaking' initiative referred to requires an explanation. Indeed, at the initiative of the Ministry of Justice, a plan for reducing the volume of lawmaking has been drafted. That plan does not, however, contradict in any way the views of the authors of this article about improving the systematicity of lawmaking. ${ }^{*}{ }^{*}$ The purpose in reducing the volume of lawmaking is to avoid excessive regulation and surplus production of laws. A precondition for drafting a new normative act is application of the principle of ultima ratio, or convincing argumentation as to its necessity and an analysis of its practical implementation. The 'less lawmaking' programme should initiate a comprehensive parliamentary process for developing a legal culture directed toward the reduction of bureaucracy.

Better lawmaking is a global priority. The European Commission emphasises as well that all member countries of the EU should participate in the process of striving towards improved legislation. It seems that accordant efforts are taking Estonia in the right direction, yet it is always possible to do better. Therefore, there is much still to be learnt from the criticism presented by the Chancellor of Justice.

In having ratified the Istanbul Convention, ${ }^{*} 4$ Estonia clearly indicates that violence is a problem in our society too; that its causes need to be determined; that prevention of violence requires systemic and legal-provisions-based co-ordinated activity; that the victims of violence need comprehensive aid, including support from the state; and that an effective prevention mechanism should be developed to counter the perpetration of violence. ${ }^{* 15}$ While some strides have been taken in this direction, the discussion of DV in Estonia began only in 2001, after the first survey of the problem. In the years since, several thorough studies of DV have been carried out in Estonia. This article considers in particular the nationwide survey of expert

11 The final report from the project Developing a Joint System for the Prevention of DV in Estonia, which was written by those authors of this article who participated in the project, recommends using the 'guidelines for development of legislative policy until 2018' output as a starting point for seeking an integrated solution to a legal code pertaining to DV. We are hopeful that a corresponding policymaking decision will be taken, since increasing political resoluteness is the first requirement for good lawmaking. The following moves should express, hone, and articulate the intent to draft a bill on DV (these steps should be to define the problem, set the objective, describe possible solutions, assess the compatibility of those prospective solutions with the national legislation, present a comparative analysis looking at the solution(s) in countries with a social organisation and legal system similar to Estonia's, and present good description of the planned regulation). See R. Narits et al. The significance of recognising domestic violence, in light of Estonian legal experts' opinion and the prospects for systematising the relevant legislation. - Juridica International 2016/24, pp. 128-138. - DOI: https://doi.org/10.12697/ji.2016.24.13.

12 See the annual review of the Chancellor of Justice for 2016-2017, available at http://www.oiguskantsler.ee/ylevaade2017/ oigusloome (most recently accessed on 6.4.2018) (in Estonian).

13 See https://www.just.ee/et/oigusloome-mahu-vahendamise-kava (most recently accessed on 6.4.2018) (in Estonian).

14 See the 2017 act of law ratifying the Council of Europe convention on preventing and combating violence against women and domestic violence: RT II, 26.9.2017, 1.

15 For discussion of the penal-law aspects of combating DV, see R. Narits et al. (see Note 11), pp. 132-135. 
legal practitioners within the framework of the 2014 project titled 'Developing a Joint System for the Prevention of DV in Estonia', supported by the Norwegian financial mechanism and the Estonian Ministry of Social Affairs ${ }^{*} 16$, and, secondly, the follow-up survey carried out in 2017.

\section{Legal practitioners' views on the causes of DV as a social problem and on factors obstructing its prevention and combating (with comparison between the 2014 and 2017 studies)}

\subsection{DV plays an important role in the work of practising legal specialists}

In 2017, a large majority of legal practitioners (71-85\%) indicated that they were handling cases of DV on a day-to-day basis, with the equivalent profession-specific figures from 2014 being $77-92 \%$ (see Table 1, below). Police detectives and prosecutors were the most heavily involved in dealing with DV, which was cited as occupying a significant proportion of their work time, nearly one third of the hours of prosecutors (29\%) and more than a third in the case of detectives (38\%), the 2014 comparative percentages being $33 \%$ and $42 \%$, respectively. A smaller share of working time was noted as spent on DV cases among judges (14\%, up slightly from 2014's 12\%) and attorneys (11\%).

Table 1: Percentages of respondents handling DV cases in their day-to-day work, as found in the surveys of expert opinions

\begin{tabular}{lccccccccc}
\cline { 2 - 9 } & \multicolumn{1}{c}{ Prosecutors } & \multicolumn{2}{c}{ Judges } & \multicolumn{2}{c}{ Attorneys* } & \multicolumn{2}{c}{ Police detectives } \\
\cline { 2 - 9 } & $\mathbf{2 0 1 4}$ & $\mathbf{2 0 1 7}$ & $\mathbf{2 0 1 4}$ & $\mathbf{2 0 1 7}$ & $\mathbf{2 0 1 4}$ & $\mathbf{2 0 1 7}$ & $\mathbf{2 0 1 4}$ & $\mathbf{2 0 1 7}$ \\
\hline $\begin{array}{l}\text { Respondents handling cases } \\
\text { of intimate-partner violence }\end{array}$ & 86 & 74 & 77 & 85 & $\ldots$ & 71 & 92 & 84 \\
\hline $\begin{array}{l}\text { Share of overall work time, } \\
\text { average }\end{array}$ & 33 & 29 & 12 & 14 & $\ldots$ & 11 & 42 & 38 \\
\hline
\end{tabular}

Sources: An Estonian Institute for Open Society Research project from 2014 and a research project of the Estonian Institute for Open Society Research and the University of Tartu Faculty of Law, titled 'Domestic Violence in Estonia', from 2017.

* No data available for attorneys for 2014 .

Every fourth prosecutor, $29 \%$ of attorneys, $15 \%$ of judges, and $16 \%$ of police detectives stated that they did not handle DV cases when surveyed in 2017.

Since the number of reported DV cases has shown a trend of rapid growth in recent years, we asked in 2017 whether this development had resulted in changes. Changes had been observed by $45-82 \%$ of respondents, prosecutors (82\%) and police detectives (75\%) above all. Most respondents had observed 'some changes' (42-66\%), while the perception of there having been 'major changes' was less extensive, at $3-16 \%$. The work of prosecutors (82\%) and police detectives (75\%) has apparently changed the most in this respect (see Table 2).

16 The methodology of the 2014 survey was developed by the Estonian Institute for Open Society Research (with the leadership of Ivi Proos and Iris Pettai) in co-operation with the University of Tartu Institute of Public Law (under Silvia Kaugia, Raul Narits, and Jüri Saar). Kati Arumäe of the Police and Border Guard Board supported it as a consultant. The methodology of the 2017 survey too was developed by the Estonian Institute for Open Society Research (in work led by Iris Pettai) in cooperation with the University of Tartu Faculty of Law (under S. Kaugia and R. Narits). The online questionnaires for both surveys were designed for prosecutors, judges, barristers, and other law specialists, along with police detectives, all over Estonia, who encounter victims of domestic violence to some extent. Participation in the survey was voluntary and anonymous. In all, 203 specialists took part in the 2014 survey and 158 in the 2017 survey. 
Table 2: Experts' opinions on the item 'The number of DV cases is increasing rapidly. Has this resulted in changes in your daily work?', as percentages

\begin{tabular}{lcccc}
\hline Speciality & Yes, major changes & Yes, some changes & No changes & Total \\
\hline Prosecutors & 16 & 66 & 18 & 100 \\
\hline Judges & - & 60 & 40 & 100 \\
\hline Attorneys & 3 & 42 & 55 & 100 \\
\hline Police detectives & 16 & 59 & 25 & 100 \\
\hline
\end{tabular}

Source: A research project of the Estonian Institute for Open Society Research and the University of Tartu Faculty of Law, titled 'Domestic Violence in Estonia', from 2017.

\subsection{Stereotype-based and prejudicial attitudes are misleading}

Estonia's legal practitioners, who clearly do encounter DV in their day-to-day work, perceive it as a quite serious problem.

In both surveys, mental and physical violence were considered a greater problem than sexual abuse is. The follow-up survey from 2017 shows that the respondents nonetheless considered all of the above-mentioned forms of violence to be rather serious problems; on the other hand, the opinion that the violence is a very serious problem has declined with regard to all forms of violence. On both occasions, respondents expressed the opinion that the most serious form is mental violence, which was profession-specifically considered a rather serious problem by $37-42 \%$ in the 2014 survey and by $54-55 \%$ in the 2017 survey. The problem following it in perceived severity was physical violence, judged a rather serious problem by $52-53 \%$ of respondents in 2014 and by $50-61 \%$ in the follow-up survey. A significant shift has occurred in the assessment of sexual violence: while it was considered rather serious by $32-33 \%$ in 2014 , the percentage rose to $33-39 \%$ in 2017 . On the other hand, it is noteworthy also that the follow-up study reveals an increase in the number of respondents who did not consider physical or sexual violence a serious problem. A feature in common between the two studies is that a significant percentage of the respondents expressed no opinion on the seriousness of various forms of violence. In fact, the follow-up study revealed a growing tendency in this regard: while $8 \%$ of legal experts took no position in relation to the seriousness of mental violence in 2014, that percentage increased to $12 \%$ with the 2017 study. The corresponding figures for physical violence are $7 \%$ and $12 \%$, respectively, while the percentage of experts not sharing an opinion with regard to sexual violence declined somewhat - among both lawyers and police detectives (the figures are presented in Table 3).

Table 3: Percentage breakdown for 'To what extent do you consider violence against women a problem in Estonia?'

\begin{tabular}{|c|c|c|c|c|c|c|c|c|c|c|c|c|}
\hline \multirow{3}{*}{$\begin{array}{c}\text { Severity } \\
\text { indicated }\end{array}$} & \multicolumn{4}{|c|}{ Mental violence } & \multicolumn{4}{|c|}{ Physical violence } & \multicolumn{4}{|c|}{ Sexual violence } \\
\hline & \multicolumn{2}{|c|}{ Lawyers } & \multicolumn{2}{|c|}{$\begin{array}{c}\text { Police } \\
\text { detectives }\end{array}$} & \multicolumn{2}{|c|}{ Lawyers } & \multicolumn{2}{|c|}{$\begin{array}{c}\text { Police } \\
\text { detectives }\end{array}$} & \multicolumn{2}{|c|}{ Lawyers } & \multicolumn{2}{|c|}{$\begin{array}{c}\text { Police } \\
\text { detectives }\end{array}$} \\
\hline & 2014 & $\mathbf{2 0 1 7}$ & 2014 & $\mathbf{2 0 1 7}$ & 2014 & $\mathbf{2 0 1 7}$ & 2014 & 2017 & 2014 & 2017 & 2014 & $\mathbf{2 0 1 7}$ \\
\hline $\begin{array}{l}\text { Very } \\
\text { serious }\end{array}$ & 44 & 32 & 49 & 41 & 39 & 38 & 42 & 32 & 19 & 14 & 20 & 16 \\
\hline $\begin{array}{l}\text { Rather } \\
\text { serious }\end{array}$ & 42 & 54 & 37 & 55 & 53 & 50 & 52 & 61 & 32 & 33 & 33 & 39 \\
\hline $\begin{array}{l}\text { Not so } \\
\text { serious }\end{array}$ & 6 & 2 & 5 & 4 & 1 & $\mathrm{O}$ & 2 & 7 & 2 & 7 & 7 & 11 \\
\hline $\begin{array}{l}\text { Unable to } \\
\text { answer }\end{array}$ & 8 & 12 & 9 & o & 7 & 12 & 4 & o & 47 & 46 & 40 & 34 \\
\hline
\end{tabular}

Sources: An Estonian Institute for Open Society Research project from 2014 and a research project of the Estonian Institute for Open Society Research and the University of Tartu Faculty of Law, titled 'Domestic Violence in Estonia', from 2017. 
While we have cited the positive finding that the percentage of law-enforcement personnel considering sexual violence a rather serious problem has increased, it is noteworthy also that the tendency not to consider sexual violence so serious a problem is growing (the figure for lawyers was $2 \%$ in 2014 and $7 \%$ in 2017, and that for police personnel was $7 \%$ in 2014 and 11\% in 2017). The cause of this development might be that legal practitioners encounter such incidents less frequently and that sexual violence is a less obvious form of violence, of which the specialists are not adequately aware.

In addition, the surveys examined perceptions as to why women become victims of physical or sexual violence and to what extent the perpetrators versus the victims were considered responsible for it. Also considered was the extent of explaining a background of violent behaviour in terms of the influence of environment. To ascertain how much women might be considered the cause, we presented for evaluation three statements blaming the female victims of violence, assuming that women cause the use of violence with their behaviour, in one way or another:

- Women provoke men to act violently by incessantly nagging, grumbling, arguing, making negative remarks, complaining, or making demands.

- Violence could be caused by women's provocative clothing or conduct.

- Women can act irresponsibly - hitchhike, get drunk, seek the company of strange men.

All three statements were supported by the respondents. Most of the respondents blamed the female victim for violence and considered her irresponsible or provocative behaviour a cause. (see Table 4). The statement supported most was the third one, about women irresponsibly hitching a ride, getting drunk, seeking the company of strange men, and provoking violence by thoughtless and stupid behaviour in general. This statement was predominantly agreed with, with $67-71 \%$ of respondents supporting it in 2017 and 61-63\% in 2014. The second-place quite widespread opinion that involves blaming women is linked with the claim that women keep nagging until the man loses self-control and becomes violent. This statement was supported by $58 \%$ of lawyers and $75 \%$ of police detectives; the 2014 figures were $63 \%$ and $77 \%$, respectively. Third most supported was the statement on provocative manner of dress and behaviour of women. This found significantly less support: only $28 \%$ of lawyers and $42 \%$ of police detectives agreed with it; the equivalent figures from 2014 were $26 \%$ and $39 \%$.

Table 4: 'Why do women become victims of physical or sexual violence?': Expert opinions of lawyers and police detectives, with percentages for 'Primarily' + 'Also'

\begin{tabular}{lllll} 
& \multicolumn{3}{c}{ Lawyers } & \multicolumn{2}{c}{ Police detectives } \\
\cline { 2 - 6 } & $\mathbf{2 0 1 4}$ & $\mathbf{2 0 1 7}$ & $\mathbf{2 0 1 4}$ & $\mathbf{2 0 1 7}$ \\
\hline I. THE CAUSE IS WOMEN, WHO... & & & & \\
\hline $\begin{array}{l}\text { act irresponsibly - hitchhike, get drunk, seek the company of } \\
\text { strange men }\end{array}$ & 63 & 67 & 61 & 71 \\
\hline provoke men by incessant nagging & 63 & 58 & 77 & 75 \\
\hline provoke men with revealing dress and provocative conduct & 26 & 28 & 39 & 42 \\
\hline $\begin{array}{l}\text { II. THE CAUSE IS MEN, WHO... } \\
\text { cannot control their aggressiveness, are irascible, and easily } \\
\text { become violent when angry }\end{array}$ & 92 & 99 & 91 & 97 \\
\hline $\begin{array}{l}\text { are overly controlling, to establish their authority and 'put women } \\
\text { in their place' }\end{array}$ & 90 & 92 & 91 & 97 \\
\hline III. VIOLENCE IS CAUSED BY... & & & & \\
\hline alcohol and narcotics & 91 & 90 & 91 & 96 \\
\hline unemployment & 57 & 58 & 68 & 79 \\
\hline poverty & 58 & 60 & 61 & 70 \\
\hline
\end{tabular}

Sources: An Estonian Institute for Open Society Research project from 2014 and a research project of the Estonian Institute for Open Society Research and the University of Tartu Faculty of Law, titled 'Domestic Violence in Estonia', from 2017 
This is a case of stereotyping attitudes, according to which the woman is guilty of violence even when she is the victim. According to a 2014 study, more than half (54\%) of Estonia's residents considered the victim partially responsible for domestic violence and approximately half (47\%) believed that women become rape victims because of their way of dressing. ${ }^{*} 17$

Supporters of the views described above presume that the victim could have avoided violence if she had not provoked the man with her irresponsible behaviour, nagging, etc., but the victim's 'incorrect conduct', long-time nagging, etc. are not actually the causes of the violence. Numerous studies have proved that the cause is the man establishing his position in intimate relationships through violence. It is typical of violent personalities to seek domination, with the individuals viewing their own desires and needs as priorities. They believe that other members of the family are 'possessions' and must be completely subordinated accordingly. Domestic violence is a serious crime, and a person using violence consistently does not do so accidentally. It is exercised deliberately, with purpose, to achieve the goal of complete authority and control over one's partner.

The two surveys of the experts show that the stereotype-based and prejudicial attitudes of blaming the victim are established and consistent; no significant changes can be observed between 2014 and 2017. Stereotypic attitudes and positions, wherein victims are blamed for violence, can obstruct the work of law-enforcement agencies. Uncertainty and fear of being blamed are among the reasons for which women suffering from violence only rarely approach law enforcement for recourse. A survey of violence against women carried out by the European Union Agency for Fundamental Rights showed that only $14 \%$ of women approach the police even after the most serious violence (the figure for Estonia is 10\%). Only every third woman seeks medical assistance after an incident of violence, while $4-6 \%$ seek out a women's shelter or victim-support service. ${ }^{*} 18$

We asked the respondents to judge also two typical statements blaming a violent man. In these, the causes of violence are presented as men's inability to control their aggression (lack of anger-management skills) and excessive need for control. These statements were supported by $88-99 \%$ of respondents. On the basis of the survey results, we can state that Estonia needs programmes targeting violent persons, (compulsory) psychological counselling, anger-management training, etc.

When comparing the respondents' evaluation of according blame for violence to either women (the victims) or men (the perpetrators), we notice that the lawyers and police detectives tend somewhat to blame men rather than women.

The effect of unemployment and poverty was considered to be among the important causes of DV, at least for $58-79 \%$ of respondents in 2017 (57-68\% in 2014). For the vast majority of respondents (90-96\% in 2017 and 92\% in 2014), causes of violence could be found in the use of alcohol and narcotics. The close relationship between the use of alcohol and DV has been verified in numerous countries. Alcohol provokes aggression and encourages violent behaviour. Furthermore, the use of alcohol is also often cited as an excuse for violent action.

The use of alcohol increases the frequency of DV and its severity. Consumption of alcohol has a direct influence on cognitive and physical functions, reduces self-control, and diminishes a person's ability to negotiate in pursuit of non-violent solutions to a conflict. ${ }^{*} 9$ Alcohol is connected with most of the incidents of violence reported, with the 2000 Scottish Crime Survey showing that $62 \%$ of perpetrators had consumed alcohol and that in $32 \%$ of cases they had used narcotic substances. Most cases involving the consumption of alcohol (83\% of them) also involved the use of narcotics. ${ }^{*}{ }^{20}$ According to police statistics for western Estonia, as many as $80 \%$ of perpetrators of violence had consumed alcohol in the time leading up to that

17 TNS Emor. Eesti elanikkonna teadlikkuse uuring soopõhise vägivalla ja inimkaubanduse valdkonnas ['Survey of Estonia’s public awareness of gender-based violence and human-trafficking']. Ministry of Social Affairs of Estonia 2014. Available at https://www.sm.ee/sites/default/files/content-editors/eesmargid_ja_tegevused/Norra_toetused/Koduse_ja_soopohise_ vagivalla_vahendamise_programm/elanike_hoiakud_soopohise_vagivalla_ja_inimkaubanduse_valdkonnas2014_aruanne_tns_emor_loplik.pdf (most recently accessed on 23.7.2015) (in Estonian).

18 According to an FRA survey from 2013, in which 4,200 women in the EU were interviewed. A fact sheet on the survey is available at http://fra.europa.eu/sites/default/files/fra-2014-vaw-survey-factsheet_et.pdf (most recently accessed on 24.7.2015) (in Estonian).

19 A. Finney. Alcohol and intimate partner violence: Key findings from the research. Findings 216. UK Home Office, March 2004. Available at http://webarchive.nationalarchives.gov.uk/20110314171826/http://rds.homeoffice.gov.uk/rds/pdfs04/ r216.pdf (most recently accessed on 4.7.2018). - DOI: https://doi.org/10.1037/e422112008-001.

20 S. MacPherson. Domestic violence: Findings from [the] 2000 Scottish Crime Survey. Scottish Executive Central Research Unit 2002. Available at http://www.scotland.gov.uk/Publications/2002/05/14413/1564 (most recently accessed on 24.7.2015). 
violence. ${ }^{* 21}$ Irrespective of the foregoing relations, alcohol is not the cause of DV. The roots of using violence are deeper than the consumption of alcohol or narcotics. Both drunken and sober men, even teetotallers, can be violent. Many men who are violent when drunk continue abusing their partners or children after sobering up. Violence need not end if/when a man gives up alcohol.

The true cause of a man's violence against his wife is his felt need to prove his power and superiority and to control her. A man with an alcohol or drugs problem who is violent hence faces two problems: the alcohol or narcotics problem and violent behaviour. The link is not always clear-cut. For instance, alcohol does not cause violent behaviour but promotes it. That said, consumption of alcohol may often be premeditated. Perpetrators of violence can cite the consumption of alcohol as an excuse for their action, claiming to have been drunk at the time. Drinking can provide socially accepted grounds for using violence. Violence accompanying drunkenness is considered quite natural in Estonia, and this readily finds acceptance within the society.

\section{The opinions of legal practitioners about legal regulation of preventing and combating DV, the corresponding institutional co-operation, and the need for consolidated law (with comparison of the 2014 and 2017 studies)}

The key issue in ensuring the victim's security and in preventing and combating violence is the ability of the state to handle the cases of DV. Several parameters are available for assessing that ability. The most important of them were included in the questionnaire for the surveys of experts. Table 5 outlines the responses. Opinions on the capability of the state varied. The greatest satisfaction, according to both surveys, is connected with the treatment of victims by law-enforcement agencies. The work done to ensure the security of the victims' children is deemed satisfactory too. The follow-up survey shows an increase (from $2 \%$ to $4 \%$ ) in the percentage of respondents believing that the state can efficiently combat DV and prevent serious cases of it. Nevertheless, respondents in both surveys indicated that the state is still facing considerable problems related to the organisation of this activity: it was seen as unsatisfactory by $65 \%$ of respondents in 2014 and by $46 \%$ in 2017 . Respondents also criticised the state for lacking control over perpetrators of violence $(73 \%$ did so in 2014 and 56\% in 2017) and over the situation in violent households (70\% in 2014, 68\% in 2017). According to the experts, the state displays an utter lack of effectiveness in providing the victims with material resources for an independent existence, even at merely subsistence level. This support was judged to be inadequate by $79 \%$ of respondents in the 2014 survey and by $61 \%$ in the 2017 one.

The experts' responses lead us to the conclusion that the state's effectiveness is less advanced in the field of prevention of DV and greater in cases that involve handling the consequences of violence. Estonia has no specific law on DV and, this could be one of the reasons for which we mainly handle the consequences of DV rather than engage in preventing it.

Just as in the 2014 survey, we asked in the follow-up whether the current legal framework allows for adequate addressing of DV (see Table 6) and whether a special act of law on domestic violence would improve the efficiency of handling of DV cases in Estonia. The respondents' opinions are presented in Table 7. Comparison between the two sets of responses shows a decline (from 15\% to 10\%) in the percentage of experts believing that the current legal framework provides for adequate handling of DV. At the same time, the number of respondents stating that it generally does not enable adequate handling has declined too (from 22 to 16\%). In both sets of survey results, a view predominates that the legal framework already in place generally allows for adequate handling of DV. It may be noteworthy that the number of respondents indicating inability to answer has increased significantly (from $4 \%$ to $12 \%$ ).

21 I. Pettai, J. Kaasik. Perevägivald politseistatistika andmetel. - Eesti edu hind. Eesti sotsiaalne julgeolek ja rahva turvalisus. Eesti Entsüklopeediakirjastus ['Domestic violence according to police statistics - the cost of Estonia's success: Estonia's social security and public safety']. 2005. 
Table 5: Percentage figures for 'How do you rate the ability of the Estonian state to handle DV cases?'

\begin{tabular}{|c|c|c|c|}
\hline \multicolumn{2}{|l|}{ Ability to... } & \multirow{2}{*}{$\begin{array}{c}2014 \\
2\end{array}$} & \multirow{2}{*}{$\begin{array}{r}2017 \\
4\end{array}$} \\
\hline \multirow{4}{*}{$\begin{array}{l}\text { 1. Combat domestic violence and prevent serious } \\
\text { cases of it }\end{array}$} & Good & & \\
\hline & Satisfactory & 27 & 36 \\
\hline & Inadequate & 64 & 46 \\
\hline & No opinion & 7 & 13 \\
\hline \multirow{4}{*}{ 2. Control the situation in violent households } & Good & 2 & 2 \\
\hline & Satisfactory & 21 & 21 \\
\hline & Inadequate & 70 & 68 \\
\hline & No opinion & 7 & 9 \\
\hline \multirow{4}{*}{$\begin{array}{l}\text { 3. Gather and maintain information about violent } \\
\text { individuals and monitor them }\end{array}$} & Good & 1 & 2 \\
\hline & Satisfactory & 20 & 27 \\
\hline & Inadequate & 73 & 56 \\
\hline & No opinion & 7 & 15 \\
\hline \multirow{4}{*}{ 4. Ensure the security of the victims' children } & Good & 4 & 10 \\
\hline & Satisfactory & 49 & 39 \\
\hline & Inadequate & 38 & 39 \\
\hline & No opinion & 8 & 12 \\
\hline \multirow{4}{*}{$\begin{array}{l}\text { 5. Provide the victims with subsistence-level material } \\
\text { resources for an independent existence }\end{array}$} & Good & 2 & 3 \\
\hline & Satisfactory & 7 & 22 \\
\hline & Inadequate & 79 & 61 \\
\hline & No opinion & 12 & 14 \\
\hline \multirow{4}{*}{$\begin{array}{l}\text { 6. Ensure safe and respectful treatment of victims } \\
\text { by law-enforcement agencies }\end{array}$} & Good & 24 & 32 \\
\hline & Satisfactory & 52 & 42 \\
\hline & Inadequate & 16 & 15 \\
\hline & No opinion & 8 & 10 \\
\hline
\end{tabular}

Sources: An Estonian Institute for Open Society Research project from 2014 and a research project of the Estonian Institute for Open Society Research and the University of Tartu Faculty of Law, titled 'Domestic Violence in Estonia', from 2017.

Table 6: Percentages for 'Do the existing legal provisions allow for adequate handling of DV cases?'

Do the existing legal provisions allow for adequate handling of domestic-violence cases?

\begin{tabular}{|lcc}
\multicolumn{1}{l}{} & $\mathbf{2 0 1 4}$ & $\mathbf{2 0 1 7}$ \\
\hline They definitely do & 15 & 10 \\
\hline They do in general & 58 & 61 \\
\hline They generally do not & 22 & 16 \\
\hline They definitely do not & 1 & 1 \\
\hline Unable to answer & 4 & 12 \\
\hline
\end{tabular}

Sources: An Estonian Institute for Open Society Research project from 2014 and a research project of the Estonian Institute for Open Society Research and the University of Tartu Faculty of Law, titled 'Domestic Violence in Estonia', from 2017. 


\subsection{A law on DV could achieve significant results}

As is noted above, Estonia has no separate law on DV, and this may be among the reasons for the focus being put primarily on dealing with the consequences of violence rather than preventing it. In consideration of this, in the survey we solicited opinions on this matter in particular: the need, if any, for a law on DV.

Table 7: 'What is your opinion on whether a separate law on DV would improve efficiency in handling of DV cases in Estonia?': Expert opinions of lawyers and police detectives, expressed as percentages

\begin{tabular}{l|cccc}
\hline \multirow{2}{*}{ Efficiency would... } & \multicolumn{2}{|c}{ Lawyers } & \multicolumn{2}{c}{ Police detectives } \\
\cline { 2 - 5 } & $\mathbf{2 0 1 7}$ & $\mathbf{2 0 1 4}$ & $\mathbf{2 0 1 7}$ & $\mathbf{2 0 1 4}$ \\
\hline Certainly improve & 4 & 9 & 7 & 25 \\
\hline Probably improve & 42 & 25 & 30 & 27 \\
\hline Probably not improve & 31 & 38 & 34 & 33 \\
\hline Certainly not improve & 11 & 19 & 2 & 7 \\
\hline Cannot answer & 12 & 9 & 27 & 8 \\
\hline Total & 100 & 100 & 100 & 100
\end{tabular}

Sources: An Estonian Institute for Open Society Research project from 2014 and a research project of the Estonian Institute for Open Society Research and the University of Tartu Faculty of Law, titled ‘Domestic Violence in Estonia', from 2017.

The respondents can be divided into supporters and sceptics with regard to their attitude towards the need for a special law on DV (see Table 7, above). The share of supporters among lawyers increased in 20142017 , from $34 \%$ to $46 \%$, and declined among police detectives, from $52 \%$ to $37 \%$. The share of sceptics has declined among lawyers correspondingly, from $57 \%$ to $42 \%$, and that among police detectives has fallen from $40 \%$ to $36 \%$. Only every tenth lawyer and $2 \%$ of police detectives showed high negativity with regard to the idea of a special law in the follow-up survey.

Several countries have successfully implemented laws on DV and have achieved remarkable results. ${ }^{{ }^{2} 2}$ We asked the respondents to judge the statements that have been used in these countries as a basis for recommending the introduction of a special law on DV.

We found that the respondents supported all the arguments employed in favour of a law specific to DV (see Table 8). The primary argument involves the organisation of co-operation among institutions. This found support among $77-86 \%$ of respondents. Taking a proactive stance and preventing serious incidents from occurring was also viewed as highly important - the corresponding statement was backed by $68-84 \%$. Two thirds of respondents emphasised the import of considering the repetitive nature of DV and of underscoring the elements specific to DV by means of the law.

Lawyers were slightly more supportive of the various arguments than police detectives were. The survey results allow us to argue that eagerness for a law on DV is considerably high among Estonia's practising legal specialists. In particular, the legal practitioners surveyed perceived numerous bottlenecks and unsolved problems in the existing legal regulation and practice, hindrances that a special law on DV would, it is hoped, overcome.

22 While a law on DV had been approved in only a single country in 1976, one has now been introduced in 140 nations. See http://www.unwomen.org/en/what-we-do/ending-violence-against-women/facts-and-figures (most recently accessed on 12.4.2018). The countries that have approved a special act in this domain (among them Austria, the UK, the USA, Australia, Germany, Spain, the Czech Republic, Slovenia, the Netherlands, Switzerland, Bulgaria, and Lithuania) have, in essence, opted for the path of consolidation for their legislation in the corresponding sphere. 
Table 8: 'How do you rate these statements supporting the implementation of a special law on DV?': Expert opinions of lawyers, with percentages for 'Completely agree' + 'Agree in general'

\section{Police detectives}

\begin{tabular}{|c|c|c|}
\hline $\begin{array}{l}\text { Organisation of co-operation: the law would establish legal provisions and } \\
\text { rules for inter-institution co-operation }\end{array}$ & 86 & 77 \\
\hline $\begin{array}{l}\text { Prevention of serious cases: the general criminal code comes into play only } \\
\text { after physical violence has already occurred. }\end{array}$ & 84 & 68 \\
\hline $\begin{array}{l}\text { Ensuring a proactive approach: the law obliges institutions encountering } \\
\text { victims to report the relevant incidents immediately }\end{array}$ & 82 & 82 \\
\hline $\begin{array}{l}\text { Considering the recurrent nature of domestic violence: in general, crimes are } \\
\text { viewed by non-special law as single acts }\end{array}$ & 64 & 61 \\
\hline $\begin{array}{l}\text { Underscoring of the elements specific to domestic violence: general criminal- } \\
\text { law acts (on assault, battery, etc.) do not consider characteristics of domestic } \\
\text { violence such as sexual abuse, damage to property, intimidation, and stalking }\end{array}$ & 64 & 60 \\
\hline
\end{tabular}

Source: A research project of the Estonian Institute for Open Society Research and the University of Tartu Faculty of Law, titled 'Domestic Violence in Estonia', from 2017

Responding to DV entails tackling two fundamental issues: how to protect the victim and how to convince the perpetrator to abandon violence. International legal practice implements two main approaches in cases of DV - punitive and conciliatory. The goal with the former is to separate the victim from the perpetrator and to punish the perpetrator, while the latter class of measures is aimed at preserving the family via conciliation of the parties, psychological counselling, anger management, etc. In clause 23 of Estonia's guidelines for development of criminal policy through to 2018, it is stipulated that when the circumstances in cases of DV so allow, the prosecutors should, working alongside the victim-support workers, implement conciliation between the victim and the perpetrator. ${ }^{{ }^{2} 3}$ Termination of criminal-law proceedings for reason of conciliation is allowed for in Estonia by §203 of the Code of Criminal Procedure. ${ }^{* 24}$ In 2017, the conciliation procedure provided for thereby was used in connection with 7,122 crimes in Estonia. In a continuation of a pattern from the year before, the largest proportion of crimes addressed in this way consisted of cases of physical maltreatment (77\%). ${ }^{*}{ }^{25}$ These statistics include DV crimes, which constitute a special case, in which the use of the conciliation procedure should pay particular attention to the specifics of this type of crime and on no account should involve putting any pressure on the victim to accept the conciliation approach $^{{ }^{2} 6}$. In addition, the effectiveness of this procedure should be assessed case-specifically.

The questionnaires addressed the conciliation procedure directly, and comparison of the results of the two surveys, as presented in Table 9, shows that the problems cited by experts are still there. The following questions remain: is there any supervision and feedback, was the agreement effective, was adequate security for the victim ensured, and has the perpetrator actually changed behaviour? The experts indicated that the content of the agreements may be too general and vague, that there can be failure to discipline the perpetrator of violence, and that half a year is too short a time for the perpetrator to mend his ways.

23 Approval of the resolution of Parliament (the Riigikogu) was given on 9 June 2010 (see 757 OE I): Guidelines for development of criminal policy until 2018, annex. See http://www.just.ee/sites/www.just.ee/files/elfinder/article_files/kriminaalpoliitika_arengusuunad_aastani_2018.pdf (most recently accessed on 3.4.2018) (in Estonian).

24 Kriminaalmenetluse seadustik (Code of Criminal Procedure). - RT I, 5.12.2017, 8.

25 Kuritegevus Eestis 2017 ['Crime in Estonia 2017’]. Tallinn: Ministry of Justice 2017, p. 22. Available at http://www. kriminaalpoliitika.ee/sites/krimipoliitika/files/elfinder/dokumendid/kuritegevuseestis_2017_veebi01.pdf (most recently accessed on 3.4.2018) (in Estonian).

26 See the stipulation based on the Istanbul Convention's Article 48: 'Prohibition of mandatory alternative dispute resolution processes or sentencing. Parties shall take the necessary legislative or other measures to prohibit mandatory alternative dispute resolution processes, including mediation and conciliation, in relation to all forms of violence covered by the scope of this Convention.' Applying a conciliation procedure in cases of violence against women is, in principle, prohibited by the UNO guidelines as well: Handbook for Legislation on Violence against Women. Available at http://www.un.org/womenwatch/daw/vaw/handbook/Handbook\%20for\%20legislation\%20on\%20violence\%20against\%20women.pdf (most recently accessed on 3.4.2018). - DOI: https://doi.org/10.18356/5e37558d-en. 
Table 9: 'How do you rate the efficiency of the conciliation procedure in DV cases?': Answer percentages for the options 'Yes, definitely' + 'Maybe'

2014 $\mathbf{2 0 1 7}$

1. It is efficient, since the perpetrator is served with the injunction he has to comply with for six months

2. The content of the agreements is often general and vague, failing to impose discipline on the perpetrator

64 63

3. Six months is too short a period for a change in the perpetrator's behaviour

4. Supervision of compliance with the conciliation terms is weak, and the victim has insufficient security to demand that the perpetrator comply with the terms

5. The initiators of the conciliation procedure (the prosecutor's office and the court) lack sufficient feedback on compliance with the agreements and any changes in the perpetrator's ways

6. Social workers and child-protection specialists with the municipality have no information about the conciliation procedure and cannot help the victim locally

7. The police receive no information about the conciliation procedure

Sources: An Estonian Institute for Open Society Research project from 2014 and a research project of the Estonian Institute for Open Society Research and the University of Tartu Faculty of Law, titled 'Domestic Violence in Estonia', from 2017.

Dealing appropriately with the perpetrators and victims of violence requires collaboration among specialists of various types. Comparisons between the two surveys with regard to respondents' opinion of their past co-operation with all specialists in this connection shows that the respondents saw an increasing need for co-operation involving law-enforcement agencies: while $7 \%$ of all respondents in the 2014 survey stated that they perceived no need for co-operation with police detectives, $5 \%$ made this claim in the 2017 followup survey; the corresponding opinion on co-operation with the prosecutor's office was held by $4 \%$ and $2 \%$, respectively; and the equivalent figures for judges were $14 \%$ and $9 \%$. The opposite pattern can be seen with regard to a felt need for co-operation with victim-support services, women's shelters, and municipal social workers: $5 \%$ of all respondents indicated that no need existed for co-operation that involves victim-support workers in 2014 and 9\% in the follow-up survey, the corresponding figures for co-operation with women's shelters' staff were $7 \%$ and $11 \%$, and those for joint work with municipal social workers were $4 \%$ and $6 \%$. This finding seems fairly problematic when one considers who was surveyed: the results reflect a belief among personnel at law-enforcement agencies that they can handle DV cases without the involvement and assistance of specialists in this field (this speciality obviously encompasses victim-support workers, staff at women's shelters, and municipal social workers). It is noteworthy also that the follow-up survey reveals an increase in the number of respondents who consider the co-operation inadequate across the board. The perceived deficiency extends to all specialists apart from victim-support services and women's shelters. The breakdown for the respondents rating the co-operation inadequate is as follows: for co-operation with police detectives, $4 \%$ in 2014 and 5\% in 2017; for that with staff of the prosecutor's office, $2 \%$ in 2014 and $3 \%$ more recently; for co-operation with judges, $6 \%$ and $6 \%$, respectively; and for work involving municipal social workers, $15 \%$ in both years. On the other hand, the majority of respondents in the follow-up survey judged their co-operation with specialists to be good. Relative to the figures from the 2014 survey, the experts reported better levels of co-operation with prosecutor's office staff (49\% of all respondents rated it good in 2014, 56\% in 2017), with judges (26\% and 33\%, respectively), and with municipal social workers (10\% and 19\%, respectively). Co-operation with other specialists was assessed to be somewhat more modest in quality in the follow-up survey as compared with the 2014 one. 